\title{
Pengaruh Pelatihan Kerja dan Insentif Terhadap Kepuasan Kerja dan Dampaknya Terhadap Komitmen Organisasional
}

(Studi Pada Karyawan PT. Bank Rakyat Indonesia (Persero) Tbk. Di Kantor Cabang Malang

Martadinata)

\author{
Helmy Adisaksana ${ }^{1}$, Endang Siti Astuti ${ }^{2}$, Mochammad Al Musadieq ${ }^{3}$ \\ ${ }^{1}$ Universitas Brawijaya \\ 2 Program Magister Administrasi Bisnis, Universitas Brawijaya
}

\begin{abstract}
ABSTRAK
Penelitian ini membahas tentang pentingnya manajemen sumberdaya manusia dalam tugasnya untuk mencapai tujuan perusahaan khusunya pada aspek pelatihan kerja, insentif, dan kepuasan kerja. Peningkatan sumberdaya manusia (karyawan) dapat ditembuh dengan berbagaicara salah satunya melalui pelatihan kerja. Dengan pelatihan kerja maka kompetensi karyawan berupa pengetahuan dan keterampilan (skill) akan meningkat, hal tersebut tentunya berdampak pada peningkatan produktifitas kerja sehingga tujuan perusahaan dapat tercapai. Tujuan penelitian ini adalah untuk mengetahui pengaruh langsung maupun tidak langsung pelatihan kerja dan insentif terhadap kepuasan kerja dan dampaknya terhadap komitmen organisasional. Jenis penelitian ini adalah penelitian eksplanatoris dengan pendekatan deskriptif kuantitatif. Penelitian ini mengambil sampel sebanyak 52 dengna menggunakan teknik sampel jenuh atau total sampling. Untuk mengetahui pengaruh tersebut data yang terkumpul dalam penelitian ini dianalisis dengan menggunakan teknik analisis jalur (path analysis). Hasil penelitian menunjukkan bahwa, terdapat pengaruh langsung maupun tidak langsung pelatihan kerja dan insentif terhadap komitmen organisasional maupun melalui kepuasan kerja sebagai variabel intervening. Dari hasil penelitian tersebut maka disarankan perusahaan perlu mempertahankan dan meningkatkan kepuasan kerja melalui pemberian pelatihan dan insentif sesuai dengan beban karyawan, menyesuaikan pekerjaan yang dilakukan karyawan dengan kemampuan diri serta minat yang dimiliki karyawan, serta ketepatan jumlah dan waktu pemberian insentif baik itu berupa bonus maupun komisi.
\end{abstract}

Kata Kunci: Manajemen sumber daya manusia, pelatihan kerja, insentif, kepuasan Kerja dan komitmen organisasional, Bank BRI.

\section{ABSTRACT}

This research discusses about the importance of human resource management in its task to reach company goal. The improvement of human resource (employee) can be conducted by many ways such as through work training. By work training, thus employee competence, which is knowledge and skill will improve, it is absolutely will be effected to the work productivity improvement thus the company goal can be reached. In order to maintain work productivity, thus the task of company is giving satisfaction guarantee to the employee. Strategy that can be conducted to give satisfaction to the employee can be conducted by giving appropriate and fair incentive. Thus, with the satisfaction from employee, it is expected that organizational commitment will appear in the employee itself. The purpose of this study was to determine the influence of direct and indirect job training and incentives on job satisfaction and its impact on organizational commitment. This type of research is explanatory research with quantitative descriptive approach. This research take 52 respondent with using total sampling. To determine the influence of the data collected in this study were analyzed using the technique of path analysis (path analysis). The results showed that, there is a direct or indirect effect of job training and incentives for organizational commitment and through job satisfaction as an intervening variable. From the research result, it can be suggested that the company needs to keep and improve work satisfaction through the training and incentive that appropriate with employee load, self ability, and also improve employee organizational commitment in order to grow sense of belonging to the organization and encourage the employee to always want to serve to the company.

Keywords: Human resource management, work training, incentive, work satisfaction and organizational commitment, BRI Bank

\footnotetext{
Alamat Korespondensi Penulis:

Helmy Adisaksana

Email : tesishelmy@gmail.com

Alamat : Jl. Raya Candi VIA/46 Karang Besuki Malang
} 


\section{Pendahuluan}

Ketatnya persaingan dalam era globalisasi harus direspon dengan menyiapkan karyawan untuk bekerja lebih profesional dan lebih memikirkan kepentingan bisnis serta perusahaan secara makro. Karyawan harus dapat mengembangkan diri, salah satunya melalui program pelatihan kerja yang dapat menunjang pelaksanaan tugasnya. Program pelatihan kerja merupakan salah satu kegiatan sumber daya manusia yang penting dalam menghadapi berbagai tantangan perusahaan di era globalisasi ini. Pada dasarnya pengembangan sumber daya manusia yang dilakukan melalui pelatihan kerja merupakan suatu usaha untuk menghilangkan adanya kesenjangan antara pengetahuan dan keterampilan karyawan sehingga tujuan perusahaan dapat tercapai [1].

PT. Bank Rakyat Indonesia (Persero) Tbk. Kantor Wilayah Malang Marta dinata menyadari bahwa sumber daya manusia merupakan faktor utama dalam pencapaian visi dan misi tersebut. Perusahaan mengharapkan seluruh karyawan menjadi orang yang profesional dan mampu bekerja sesuai standar perusahaan dalam menjalankan tugasnya sehari-hari. Oleh karena itu PT. Bank Rakyat Indonesia (Persero) Tbk. Kantor Wilayah Malang Martadinata selalu berupaya untuk meningkatkan kualitas sumber daya manusia dengan pelatihan kerja. Seperti yang dikemukakan [2] yakni "pelatihan kerja dan pengembangan mempunyai berbagai manfaat karier jangka panjang yang membantu karyawan untuk mengemban tanggung jawab lebih besar di masa yang akan datang". Program pelatihan kerja tidak hanya penting bagi individu, tetapi juga organisasi dan hubungan karyawan dalam kelompok kerja". Maka dari itu metode yang paling mudah untuk meringkas manfaat pelatihan kerja adalah dengan menyadarinya bahwa pelatihan kerja merupakan sebuah investasi organisasi yang masuk dalam ranah manajemen sumber daya manusia.

Menurut [3] tujuan yang ingin dicapai dari adanya program pelatihan kerja adalah: (1) memperbaiki moral kerja karyawan; (2) memperbaiki kinerja karyawan; (3) menjaga dan memperbaiki alat usaha seperti mesin-mesin atau perlatan produksi; (4) menambah stabilitas dan fleksibilitas karyawan; (5) menambah semangat kerja karyawan; (6) meminimalisir sistem pengawasan yang tidak perlu; (7) serta meningkatkan kemandirian kerja karyawan.

Menciptakan sistem kerja yang baik masih belum cukup membuat pegawai bekerja dengan sebaik-baiknya dalam rangka mencapai kepuasan kerjadan komitmen terbaik. Sebagai imbalannya, perusahaan perlu memperhatikan kesejahteraan pegawai. Tolak ukur pertama bagi pegawai adalah besarnya gaji yang diterima dari perusahaan. Untuk meningkatkan kepuasan kerja dan komitmen pegawai, maka perusahaan dapat menerapkan insentif. Insentif merupakan penghargaan/imbalan yang diberikan untuk memotivasi pekerja atau anggota organisasi supaya produktivitas kerjanya tinggi, [4].

Pemberian insentif merupakan salah satu cara yang tepat untuk memotivasi karyawan, sebab dengan diberikannya insentif yang adil, proporsional, dan bersifat progressive, yaitu sesuai dengan jenjang karir, maka akan memacu kinerja para karyawan agar selalu bekerja optimal. Pimpinan yang adil, bijaksana, dihargai oleh masyarakat, dan perusahaan yang mempunyai nama baik akan membuat karyawan betah serta memiliki komitmen yang kuat untuk tetap bekerja di perusahaan tersebut [5]. Seorang karyawan cenderung berusaha lebih giat apabila insentif yang diterima memberikan kepuasan kerja terhadap apa yang diharapkan. Dengan demikian pemberian insentif akan lebih memotivasi pegawai untuk meningkatkan produktivitas kerjanya karena tewujudnya kepuasan kerja dalam diri karyawan tersebut.

Kepuasan kerja mengacu pada reaksi emosional positif individu untuk pekerjaan tertentu. Untuk membantu memahami konsep kepuasan kerja, [6] mendefinisikan kepuasan kerja sebagai suatu keadaan emosional yang menyenangkan atau positif yang dihasilkan dari penilaian pekerjaan atau pengalaman pekerjaan. Kepuasan kerja merupakan kumpulan perasaan seseorang untuk bertahan pada pekerjaannya termasuk semua aspek pekerjaan tertentu, baik dan buruk, positif atau negatif, yang mungkin berkontribusi pada pengembangan perasaan kepuasan atau ketidak puasan.

Kepuasan kerja berkaitan dengan bagaimana orang merasa tentang pekerjaan mereka dan aspek yang berbeda dari pekerjaan mereka. Hal ini adalah sejauh mana orang-orang suka (kepuasan) atau tidak suka (ketidakpuasan) pada pekerjaan mereka [6]. Namun, apa yang membuat pekerjaan memuaskan atau tidak memuaskan tidak hanya tergantung pada sifat dari pekerjaan, tetapi juga pada harapan bahwa individu mendapatkan apa yang seharusnya disediakan dari pekerjaan mereka.

Menurut [7] kepuasan kerja berdimensi sangat luas, secara garis besar mencakup tantangan dalam kerja, imbalan dan penghargaan yang wajar, kondisi dan rekan kerja yang mendukung, serta kesesuaian pekerjaan dengan kepribadian karyawan. Hasil jurnal penelitian yang dilakukan oleh Stephen [8] "Using training and development 
to affect job satisfaction within franchising" (pengaruh penerapan pelatihan kerja dan pengembangan terhadap kepuasan kerja pada karyawan perusahaan franchise) hasil penelitian membuktikan bahwa kualitas pelatihan kerja dan pengembangan sangat berpengaruh signifikan terhadap kepuasan kerja. Selain itu kepuasan kerja karyawan juga dipengaruhi oleh lingkungan kerja, nilai-nilai perusahaan dan tanggung jawab pekerjaan serta komitmen organisasional.

Komitmen organisasional merupakan sifat hubungan antara individu dengan organisasi kerja. Komitmen organisasional merupakan sebuah interpretasi dari individu yang berbentuk keyakinan diri terhadap nilai-nilai dan tujuan organisasi kerja, kerelaan untuk menggunakan usahanya secara sungguh-sungguh demi kepentingan organisasi kerja serta mempunyai keinginan yang kuat untuk tetap menjadi bagian dari organisasi kerja. Sementara komitmen organisasional yang terkait dengan pekerjaan akan bersinggungan dengan banyak hal dalam lingkup organisasi. Untuk Komitmen organisasional dapat dipandang pada beberapa konteks meliputi komitmen organisasional karyawan pada atasan, rekan kerja, pekerjaan atau organisasi itu sendiri.

Karyawan yang bisa menjadi objek penelitian merupakan karyawan tetap dan memiliki keinginan untuk menggunakan usaha yang sesuai dengan tujuan organisasi. Sebaliknya karyawan yang terpaksa menjadi anggota akan menghindari kerugian finansial dan kerugian lain, sehingga karyawan tersebut hanya melakukan usaha yang tidak maksimal. Sementara itu, komitmen normatif yang berkembang sebagai hasil dari pengalaman sosialisasi bergantung dari sejauh apa perasaan kewajiban yang dimiliki karyawan. Komitmen normatif menimbulkan perasaan kewajiban pada karyawan untuk memberi balasan atas apa yang telah diterima dari.

PT. Bank Rakyat Indonesia (BRI) adalah sebuah perusahaan yang bergerak di bidang jasa perbankan. PT. Bank Rakyat Indonesia merupakan bank pemerintah pertama dan terbesar yang konsisten memfokuskan diri pada pelayanan kepada masyarakat kecil, diantaranya dengan memberikan fasilitas kredit kepada golongan pengusaha kecil. Bidang-bidang pekerjaan yang terdapat di PT. Bank Rakyat Indonesia (Persero) Tbk. Kantor Wilayah Malang Martadinataantara lain bagian accountofficer, frontliner, administrasi, Back office, SDM, Officer Development Program (ODP), management trainee dan masing-masing bidang memiliki karakteristik pekerjaan tersendiri. Terdapat pekerjaan yang membutuhkan kreativitas, ide, terobosan, keahlian, ada juga jenis pekerjaan yang bersifat rutinitas. Pelatihan kerja selalu diberikan kepada setiap karyawan yang baru masuk maupun karyawan lama jika terdapat program dan aturan baru yang harus diterapkan. Dengan adanya pelatihan kerja tersebut PT. Bank Rakyat Indonesia (Persero) TBK. Kantor Wilayah Malang Martadinata mampu menjaga standar dan kualitas kerja yang ditentukan. Perusahaan yang didirikan pada tahun 1946 dan berpusat di kota Malang ini memiliki segmen di bidang jasa perbankan, sehingga pelayanan dan kepuasan pelanggan merupakan tujuan utama disamping profit yang telah menjadi target perusahaan. Berdasarkan latar belakang yang telah dipaparkann maka dapat diketahui rumusan masalah sebagai berikut:

a. Bagaimana gambaran tentang pelatihan kerja, insentif, kepuasan kerja dan komitmen organisasional di PT. Bank Rakyat Indonesia (Persero) Tbk. Kantor Wilayah Malang Martadinata?

b. Apakah terdapat pengaruh pelatihan kerja terhadap kepuasan kerja di PT. Bank Rakyat Indonesia (Persero) Tbk. Kantor Wilayah Malang Martadinata?

c. Apakah terdapat pengaruh insentif terhadap kepuasan kerja di PT. Bank Rakyat Indonesia (Persero) Tbk. Kantor Wilayah Malang Martadinata?

d. Apakah terdapat pengaruh pelatihan kerja terhadap komitmen organisasional di PT. Bank Rakyat Indonesia (Persero) Tbk. Kantor Wilayah Malang Martadinata?

e. Apakah terdapat pengaruh insentif terhadap komitmen organisasional di PT. Bank Rakyat Indonesia (Persero) Tbk. Kantor Wilayah Malang Marta dinata?

f. Apakah terdapat pengaruh kepuasan kerja terhadap komitmen organisasional di PT. Bank Rakyat Indonesia (Persero) Tbk. Kantor Wilayah Malang Martadinata?

Seperti yang dikemukakan [9], tujuan pelatihan kerja adalah: (1) Untuk mempelajari prosedur pekerjaan; (2) Penjalinan hubungan dengan atasan dan bawahan; (3) Memberikan karyawan perasaan memiliki dengan memperlihatkan bagaimana pekerjaan mereka sejalan dengan keseluruhan organisasi; (4) Mengurangi jumlah stres dan kegelisahan yang dialami oleh karyawan baru. Dengan adanya pelatihan kerja maka akan terjalin komunikasi yang baik. Tujuan pelatihan kerja yang dijabarkan oleh Simamora akan berdampak pada kepuasan kerja karyawan. Jika karyawan menguasai prosedur pekerjaannya maka dia akan dengan mudah menyelesaikan pekerjaannya. Begitu juga ketika terjalin hubungan yang baik dengan atasan atau bawahan, suasana kerja akan menjadi nyaman. 
Seiring berjalannya waktu maka karyawan akan merasa ikut memiliki terhadap perusahaan. Hal serupa juga diungkapkan oleh [10] dalam hasil penelitiannya menyatakan bahwa terdapat pengaruh yang signifikan pelatihan kerja dan kepuasan kerja terhadap produktifitas kerja.

Ada beberapa teori yang dapat mengungkapkan kepuasan kerja karyawan, salah satunya adalah Two Factor Theory, yaitu teori yang beranggapan bahwa kepuasan kerja dan ketidakpuasan kerja merupakan dua hal yang berbeda. Sehingga dapat diartikan bahwakepuasan dan ketidakpuasan terhadap pekerjaan itu tidak merupakan suatu variabel yang kontinyu. Teori ini pertama kali dikemukakan oleh Frederick [5] Satisfiers (motivator) ialah faktor-faktor atau situasi yang dibuktikannya sebagai sumber kepuasan kerja yang terdiri dari: pencapaian (achievement) yakni besar kecilnya tenaga kerja mencapai prestasi kerja yang tinggi; pengakuan (recognition) yakni besar kecilnya pengakuan yang dirasakan dan diberikan pada tenaga kerja dan kemajuan (advancement) yakni besar kecilnya kemungkinan tenaga kerja dapat maju dalam pekerjaannya. Hadirnya faktor ini akan menimbulkan kepuasan, tetapi tidak hadirnya faktor ini tidaklah selalu mengakibatkan ketidakpuasan. Dissatisfiers (hygiene faktor) ialah faktor-faktor yang terbukti menjadi sumber ketidakpuasan, yang terdiri dari: kebijakan perusahaan (companypolicy and administration) yakni derajat kesesuaian yang dirasakan tenaga kerja dari semua kebijakan dan peraturan yang berlaku diperusahaan; penyeliaan (supervision technical) yakni derajat kewajaran penyeliaan yang dirasakan oleh tenaga kerja; gaji (salary) yakni derajat kewajaransuatu imbalan atas hasil kerjanya; hubungan antar pribadi (interpersonal relations) yakni derajat kesesuaian yang dirasakan dalam berinteraksi dengan tenaga kerja lainnya, dan kondisi kerja (workingcondition) yakni derajat kesesuaian kondisi kerja dengan proses pelaksanaan pekerjaannya. Perbaikan terhadap kondisi atau situasi ini akan mengurangi atau menghilangkan ketidakpuasan, tetapi tidak akan menimbulkan kepuasan karena ia bukan sumber kepuasan kerja [11]. Kepuasan kerja merupakan kumpulan perasaan seseorang untuk bertahan pada pekerjaannya termasuk semua aspek pekerjaan tertentu, baik dan buruk, positif atau negatif, yang mungkin berkontribusi pada pengembangan perasaan kepuasan atau ketidakpuasan.

Hasil penelitian ini menunjukkan kompensasi merupakan salah satu faktor yang dipengaruhi pada kepuasan kerja dan kinerja karyawan. Kompensasi terbagi menjadi kompensasi finansial terdiri dari gaji, bayaran prestasi, bayaran insentif, bayaran diluar jam kerja, program perlindungan dan kompensasi non finansial terdiri dari pekerjaan. Kedua unsur ini akan berpengaruh pada meningkatnya kepuasan dan kinerja karyawan. Data penelitian ini mendapatkan beberapa kesimpulan penting bahwa kompensasi sangat penting bagi karyawan dalam upaya meningkatkan kepuasan dan kinerja karyawan di lingkungan kerja.

Menurut Kadarisman (2012) "insentif adalah penghargaan atau imbalan yang diberikan untuk memotivasi pekerja/anggota organisasi agar motivasi dan produktivitas kerjanya tinggi, sifatnya tidak tetap atau sewaktu-waktu “. Sedangkan menurut Hariandja (2002) insentif merupakan salah satu jenis pengahargaan yang dikaitkan dengan prestasi kerja. Semakin tinggi prestasi kerja semakin besar pula insentif yang diterima. Sudah menjadi kebiasaan bahwa setiap perusahaan harus menetapkan target yang tinggi dan bila berhasil maka akan diberikan tambahan pendapatan.

Perusahaan juga berusaha agar karyawannya bisa bekerja maksimal. Pekerjaan bisa dikerjakan dengan maksimal ketika karyawan merasa senang untuk bekerja di perusahaan. Dalam penelitiannya yang menitikberatkan pada kompensasi yang turut mempengaruhi kepuasan kerja karyawan. Apabila kompensasi yang diberikan perusahaan telah sesuai dengan harapan karyawan, maka karyawan akan lebih terpuaskan dalam pekerjaannya sehingga out put yang dihasilkan karyawan juga akan baik dan organisasi juga dapat mencapai sasaran organisasinya. Kemudian disimpulkan bahwa terdapat pengaruh yang signifikan kompensasi terhadap kepuasan kerja karyawan PD BPR BKK Boyolali. Selain itu penelitian L Rogers (2008) yang berjudul "Effect Of Non-Financial Incentives (Job Enrichment, Employee Recognition) On Job Satisfaction And Organizational Commitmen" menyatakan bahwa pemberian insentif berpegaruh signifikan terhadap kepuasan kerja karyawan.

Penelitian ini yang dilakukan dengan analisis path menujukkan bahwa variabel insentif material (X1) mempunyai pengaruh langsung yang signifikan terhadap kepuasan kerja (Y1) dengan nilai sebesar 0,381. Variabel insentif non material (X2) mempunyai pengaruh langsung yang signifikan terhadap kepuasan kerja (Y1) dengan nilai sebesar 0,452 . Variabel insentif material (X1) mempunyai pengaruh langsung yang signifikan terhadap kinerja karyawan (Y2) dengan nilai sebesar 0,403. Variabel insentif non material (X2) mempunyai pengaruh langsung yang signifikan terhadap kinerja karyawan (Y2) dengan nilai sebesar 0,327. Yang terakhir, variabel kepuasan kerja (Y1) berpengaruh langsung 
yang signifikan terhadap kinerja karyawan (Y2) dengan sebesar 0,200.

Berdasarkan tujuan pelatihan kerja menurut [9] yakni pelatihan kerja dapat menyelaraskan tujuan perusahaan dan perasaan karyawan serta menjalin hubungan baik antara atasan dan bawahan maka hal tersebut dapat berpengaruh terhadap komitmen organisasional karena dengan eratnya hubungan antara atasan dan bawahan serta terjalinnya keselarasan antara individu dan organisasi akan membuat pegawai semakin loyal dan berkomitmen terhadap organisasi. Hal ini memang banyak terbukti pada kehidupan nyata, bahwa kenyamanan di dalam suasana kerja serta timbulnya rasa memiliki akan berdampak pada komitmen organisasional karyawan tersebut. Komitmen organisasional adalah kekuatan identifikasi dan keterlibatan individu di dalam suatu organisasi. Ini mencerminkan kepercayaan karyawan pada tujuan dan misi organisasi, kesediaan untuk memberikan usahanya untuk penyelesaian pekerjaan, dan sebuah niat untuk tetap bekerja di organisasi tersebut [13].

Penelitian dari [14], menyatakan bahwa terdapat pengaruh positif dan signifikan pelatihan kerja dengan komitmen organisasional.

Komitmen organisasional merupakan sifat hubungan antara individu dengan organisasi kerja, dimana individu mempunyai keyakinan diri terhadap nilai-nilai dan tujuan organisasi kerja, adanya kerelaan untuk menggunakan usahanya secara sungguh-sungguh demi kepentingan organisasi kerja serta mempunyai keinginan yang kuat untuk tetap menjadi bagian dari organisasi kerja. Sementara Komitmen organisasional yang terkait dengan pekerjaan akan bersinggungan dengan banyak hal dalam lingkup organisasi. Komitmen organisasional dapat dipandang pada beberapa konteks meliputi Komitmen organisasional karyawan pada atasan, rekan kerja, pekerjaan atau organisasi.

Motivasi harus diberikan kepada keryawan, karena ini adalah salah satu usaha perusahaan agar karyawannya dapat bekerja maksimal. Motivasi dapat berupa insentif. Seperti pada penelitian yang berjudul pengaruh pemberian insentif terhadap komitmen organisasional karyawan PT. Bank Rakyat Indonesia cabang Lubuk Pakam menjelaskan bahwa hasil penelitian menunjukan pemberian insentif berpengaruh positif dan signifikan terhadap komitmen organisasional karyawan. Selain itu juga memaparkan bahwa hasil penelitiannya menyimpulkan secara simultan insentif serta pendidikan dan pelatihan berpengaruh terhadap kinerja guru.
Penelitian ini didukung oleh, hasil pengolahan data dengan menggunakan metode regresi sederhana dan analisis jalur menghasilkan empat penemuan sesuai dengan hipotesis yang telah diajukan. Pertama, terdapat pengaruh yang signifikan antara kepuasan kerja dengan komitmen organisasional karyawan. Kedua, terdapat pengaruh yang signifikan antara Komitmen organisasional dengan kinerja karyawan. Ketiga, terdapat pengaruh yang signifikan antara kepuasan kerja terhadap kinerja karyawan dengan motivasi sebagai variabel intervening. Keempat, terdapat pengaruh yang signifikan antara Komitmen organisasional terhadap kinerja karyawan, tetapi motivasi tidak dapat sebagai variabel intervening.

Locke [15] mendefinisikan kepuasan kerja sebagai suatu keadaan emosional yang menyenangkan atau positif yang dihasilkan dari penilaian pekerjaan atau pengalaman pekerjaan. Kepuasan kerja merupakan kumpulan perasaan seseorang untuk bertahan pada pekerjaannya termasuk semua aspek pekerjaan tertentu, baik dan buruk, positif atau negatif, yang mungkin berkontribusi pada pengembangan perasaan kepuasan atau ketidakpuasan. Kepuasan kerja mengacu pada reaksi emosional positif individu untuk pekerjaan tertentu. Kepuasan kerja merupakan suatu perasaan seseorang mengenai pekerjaan mereka dan aspek yang berbeda dari pekerjaan mereka. Derajat kepuasan kerja adalah sejauh mana orang-orang suka (kepuasan) atau tidak suka (ketidakpuasan) pada pekerjaan mereka Secara konseptual, kepuasan kerja berpengaruh terhadap komitmen organisasional. Hal ini sejalan dengan tujuan dari penelitian [16]. Hasil penelitian menunjukkan Pertama terdapat pengaruh yang signifikan antara kepuasan kerja dengan komitmen organisasional karyawan. Kedua, terdapat pengaruh yang signifikan antara komitmen organisasional dengan kinerja karyawan. Ketiga, terdapat pengaruh yang signifikan antara kepuasan kerja terhadap kinerja karyawan dengan motivasi sebagai variabel intervening. Keempat, terdapat pengaruh yang signifikan antara komitmen organisasional terhadap kinerja karyawan, tetapi motivasi tidak dapat sebagai variabel intervening. Hal ini dapat dikonstruksikan pada gambar berikut.

Berdasarkan latar belakang, rumusan masalah, tujuan penelitian, dan hasil penelitian terdahulu dalam meneliti pengaruh pelatihan kerja dan insentif terhadap kepuasan kerja dan dampaknya terhadap komitmen organisasional, maka dapat digambarkan dalam bentuk gambar model konseptual; 


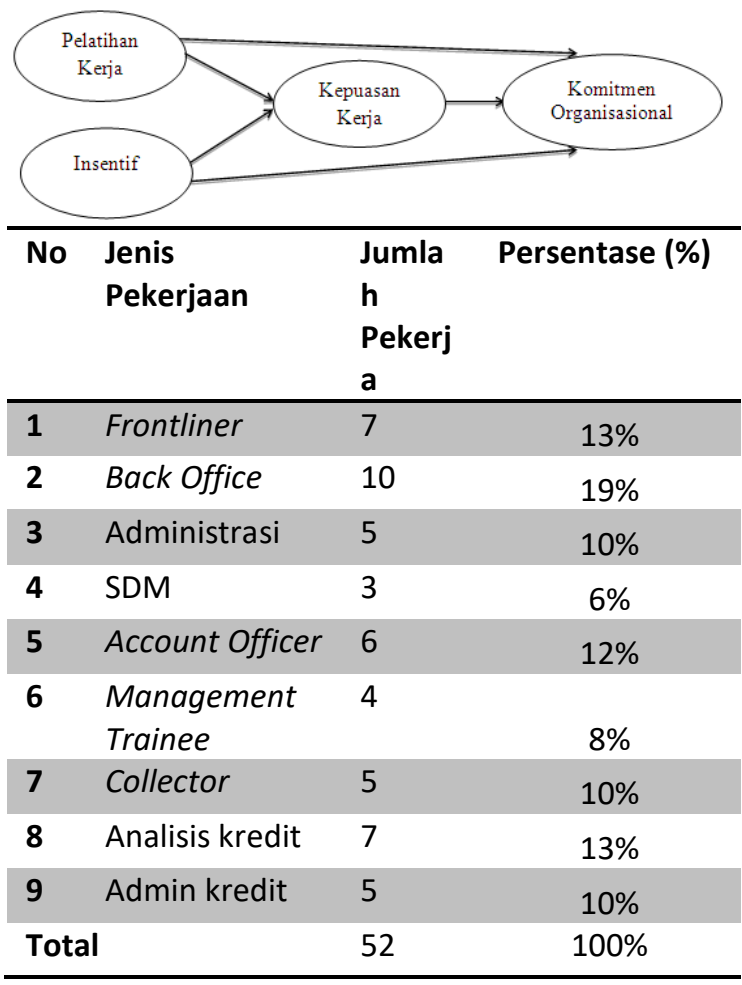

Gambar 1. Model Konseptual

Metode Penelitian

Penelitian merupakan suatu cara sistematis untuk meneliti dan mengkaji suatu fenomena dengan menggunakan metode ilmiah dan aturan-aturan yang berlaku. Menurut Unarjan (2003) "metode penelitian adalah semua asas, peraturan dan teknik-teknik yang perlu diperhatikan dan diterapkan dalam usaha pengumpulan data dan analisa".

Selain format deskriptif, jenis penelitian yang akan digunakan dalam penelitian ini adalah penelitian eksplanatori atau penelitian yang diarahkan untuk menjelaskan suatu keadaan atau situasi [18]. Jenis penelitian eksplanatori tersebut sama dengan korelasional, dimana pada metode ini dijelaskan hubungan atau pengaruh antara variabel yang diteliti. Metode korelasi ini bertujuan untuk meneliti sejauh mana variabel pada satu faktor berpengaruh terhadap variabel pada faktor lainnya.

Sehubungan dengan tujuan penelitian maka secara keseluruhan ini menggunakan metode survey, yaitu penelitian yang diperoleh dari pengambilan sampel suatu populasi dan menggunakan kuesioner sebagai alat pengumpulan data yang pokok [20].

Lokasi penelitian adalah tempat dimana penelitian dilakukan. Penelitian ini dilakukan di PT. Bank Rakyat Indonesia (Persero) Tbk. Kantor Wilayah Malang Martadinata yang berpusat di Jalan Jl. Laksamana Martadinata No. 80 Kota Malang.

Populasi adalah wilayah generalisasi yang terdiri dari objek atau subjek yang menjadi kuantitas dan karakteristik tertentu yang ditetapkan oleh peneliti untuk dipelajari dan kemudian ditarik kesimpulannya. Senada dengan pendapat tersebut, juga mengungkapkan bahwa populasi adalah seluruh data yang menjadi perhatian kita dalam suatu ruang lingkup dan waktu yang kita tentukan. Sehingga dalam ruang lingkup penelitian ini, populasi dalam penelitian adalah seluruh karyawan yang bekerja di PT. Bank Rakyat Indonesia Tbk. Kantor Wilayah Malang Martadinata. Jumlah karyawan yang bekerja di PT. Bank Rakyat Indonesia Tbk. Kantor Wilayah Malang Martadinata adalah 52 orang karyawan, dimana masing-masing karyawan tersebut sudah memiliki job dis masing-masing. Tabel 1 menunjukkan jumlah karyawan yang terbagi dengan jenis pekerjaan masing-masing di PT. Bank Rakyat Indonesia Tbk. Kantor Wilayah Malang Martadinata.

Tabel 1 Jumlah Karyawan dan Jenis Pekerjaan Sumber: PT. Bank Rakyat Indonesia (PERSERO) Tbk. Kantor Wilayah Malang Martadinata.

Teknik pengambilan sampel yang akan digunakan dalam penelitian ini adalah sampling jenuh. Sampling jenuh adalah cara pengambilan sampel dengan mengambil semua anggota populasi menjadi sampel. Cara ini dilakukan apabila populasinya kecil dan istilah lain sampling jenuh adalah sensus. Jumlah karyawan yang bekerja di PT. Bank Rakyat Indonesia Tbk. Kantor Wilayah Malang Martadinata adalah 52 orang karyawan, dengan demikian jumlah sampel pada penelitian ini sebanyak 52 orang.

\section{Hasil dan Pembahasan}

Hasil analisis jalur akan digunakan untuk melihat pengaruh antar variabel dengan melihat taraf signifikasi antar variabel, serta hubungan antar variabel. Untuk melihat pengaruh antar variabel dapat dilihat dari besarnya nilai Adjusted $R$ Square $\left(r^{2}\right)$ dengan cara menghitung besarnya Koefisien Determinasi (KD) menggunakan rumus $K D=r^{2} \times 100 \%$. Sedangkan untuk melihat taraf signifikasi antar variabel digunakan Sig penelitian, jika Sig penelitianlebih kecil dari 0,05 (Sig s 0,05), maka dinyatakan terdapat pengaruh signifikan antar variabel. Jika nilai Sig penelitian lebih besar dari nilai 0,05 (Sig $\geq 0,05$ ), maka dinyatakan pengaruh antar variabel tidak signifikan atau dapat juga dilihat dengan menggunakan uji t. Apabila nilai thitung lebih besar dari $t_{\text {tabel }}$ ( $t_{\text {hitung }}>t_{\text {tabel }}$ ) maka pengaruh antar variabel adalah signifikan.Sebaliknya jika nilai thitung lebih kecil dari $t_{\text {tabel }}$ ( (thitung $<t_{\text {tabel }}$ ) maka pengaruh antar variabel adalah tidak signifikan. 
Tabel 2 Hasil Uji Koefisien Jalur Pengaruh Varabel Pelatihan Kerja (X1) dan Insentif (X2) Terhadap Kepuasan Kerja (Y1)

\begin{tabular}{|c|c|c|c|}
\hline Variabel & Beta & t-hitung & P-Value \\
\hline Pelatihan Kerja & 0.212 & 2.111 & 0.012 \\
\hline Insentif & 0.836 & 7.502 & 0.000 \\
\hline$r^{2}=0.684$ & \multirow{2}{*}{\multicolumn{3}{|c|}{ Nilai Kritis t-tabel $=2.007$}} \\
\hline$K D=68.4$ & & & \\
\hline
\end{tabular}

Sumber: Lampiran 6

Tabel 2 menunjukkan bahwa hasil pengujian pengaruh variabel pelatihan kerja (X1) dan Intensif (X2), terhadap kepuasan kerja (Y1) mempunyai $r^{2}$ sebesar 0.684 atau koefisien determinasi (KD) sebesar 68,4. hasil ini menjelaskan bahwa hasil pengujian pengaruh dari variabel pelatihan kerja (X1) dan Intensif (X2) memberi kontribusi pengaruh sebesar 68,4\% terhadap variabel kepuasan kerja (Y1).

Berdasarkan hasil pehitungan statistik pengaruh variabel pelatihan kerja (X1) terhadap variabel kepuasan kerja (Y1) menunjukkan thitung sebesar 2,111, nilai $p$-value sebesar 0,012 dan koefisien (beta) sebesar 0,212 .Hasil uji $t$ menggambarkan bahwa thitung lebih besar tabel $(2,111>2,007)$.Berdasarkan $p$-value dimana hasil perhitungan menunjukkan bahwa $p$-value lebih kecil dari signifikan $(0,012)$. Hasil ini dapat dijelaskan bahwa nilai thitung lebih besar thitung dan nilai pvalue lebih kecil dari nilai signifikan.niali koefisien jalur (beta) memiliki angka positif, maka hasilnya adalah signifikan dan positif. Hal ini disimpulkan menunjukkan bahwa variabel kepuasan kerja (Y1) dapat dijelaskan secara langsung oleh variabel pelatihan kerja (X1).

Hasil perhitungan statistik variabel Intensif (X2) terhadap variabel kepuasan kerja (Y1) menunjukkan thitung sebesar 7,502, nilai p-value sebesar 0,000 dan koefosien jalur (beta) sebesar 0,836 . Hasil uji t menggambarkan bahwa thitung lebih besar dari tabel $(7,502>2,007)$. Berdasarkan P-value dimana hasil perhitungan menunjukkan bahwa $\mathrm{p}$ value lebih kecil dari nilai signifikan $(0,000<0,005)$. Hasil ini dapat dijelaskan bahwa nilai thitung lebih besar dari $t$ tabel dan nilai $p$-value lebih kecil dari nilai signifikasi.Serta nilai koesfisean jalur (beta) memiliki angka positif, maka hasilnya signifikan dan positif.Hasil ini dapat disimpulkan, menunjukkan bahwa variabel kepuasan kerja (Y1) dapat dijelaskan secara langsung oleh variabel intensif (X2).

Tabel 3 Hasil Uji Koefisien Jalur Pengaruh Varabel

Pelatihan Kerja (X1),Insentif (X2) dan Kepuasan Kerja (Y1), Terhadap Komitmen Organisasional (Y2)

\begin{tabular}{|c|c|c|c|}
\hline Variabel & Beta & t-hitung & P-Value \\
\hline Pelatihan Kerja & 0.014 & 2.256 & 0.009 \\
\hline Insentif & 0.511 & 6.495 & 0,000 \\
\hline Kepuasan Kerja & 0.488 & 7.09 & 0,000 \\
\cline { 1 - 2 } $\mathrm{r}^{2}=0.928$ & \multicolumn{3}{|c}{ Nilai Kritis t-tabel $=2.007$} \\
\cline { 1 - 2 } KD=92.8 & \multicolumn{3}{|c}{} \\
\cline { 1 - 2 }
\end{tabular}

Sumber: Lampiran 16

Tabel 3 menunjukkan bahwa hasil poengujian pengaruh variabel pelatihan kerja (X1), Intensif (X2) dan kepuasan kerja (Y1) terhadap komitmen organisasional (Y2) mempunyai $r^{2}$ sebesar 0,928atau koefisien determinasi (KD) sebesar 92,8. Hal ini menjelaskan bahwa hasil pengujian pengaruh dari variabel pelatihan kerja (X1), Intensif (X2) dan kepuasan kerja (Y1) memberi kontribusi pengaruh sebesar 92,8\% terhadap variabel komitmen organisasional (X2).

Berdasarkan hasil perhitungan statistik pengaruh variabel pelatiahan kerja (X1) terhadap variabel komitmen organisasional (Y2) menunjukkan thitung sebesar 0,256, nilai $p$-value sebesar 0,009dan koefisien jalur (beta)sebesar 0,014 . Hasil uji t menggambarkan bahwa thitung lebih besar dari tabel $(2,256>2,007)$. Berdasarkan P-Value dimana hasil perhitungan menunjukkan bahwa $p$ value lebih kecil dari nilai signifikansi $(0,009<0,05)$. Hasil ini dapat dijelaskan bahwa nilai thitung lebih besar dari tabel dan nilai $p$-value lebih kecil dari nilai signifikansi, serta nilai koefisiean jalur (beta) memiliki angka positif, maka hasilnya adalah signifikan dan positif.Hasil ini menunjukkan bahwa variabel komitmen organisasional (Y2) dapat dijelaskan secara langsung oleh variabel pelatihan kerja (X1).

Hipotesis kedua $(\mathrm{H} 1)$ yang menyatakan bahwa pelatihan kerja berpengaruh signifikan terhadap kepuasan kerja dapat diterima. Hal ini dapat dibuktikan melalui uji regresi dimana nilai probabilitas ( $p$-value) sebesar 0,012 yang lebih kecil dari nilai signifikansi 0,05 yang menunjukkan hasil yang signifikan. Ini member makna bahwa pelatihan kerja emmpunyai pengaruh yang signifikan terhadap kepuasan kerja. Data pada statistic deskriptif juga menunjukkan skor mean variabel pelatihan kerja sebesar 4,27dan variabel kepuasan kerja 4,33 dimana skor mean keduanya termasuk kategori sangat tinggi. Data ini mendukung bahwa penerapan pelatihan kerja yangbaik akan menghasilkan kepuasan karyawan. Koefisien jalur sebesar 0,212 mengindikasikan bahwa pengaruh pelatihan kerja terhadap kepuasan kerja adalah positif. Artinya, semakin baik persepsi karyawan terhadap pelatihan kerja yang diberikan oleh perusahan maka akansemakin tinggi pula persepsi karyawan 
terhadap kepuasan kerja. Demikian pula sebaliknya, ketika persepsi pelatihan kerja buruk maka persepsi karyawan terhadap kepuasan kerja juga akan rendah. Berdasarkan jawaban responden dari angket yang terkumpul, dari indicator kepuasan terhadap pelatihan $(X 1,4)$ memiliki skor mean 4,35 yang termasuk dalam rentang sangat tinggi dengan item karyawan merasa puas karena diberikan pelatihan keja yang diberikan sesuai dengan kebutuhan karyawan $(X 1,4,1)$. Persepsi terhadap item ini adalah karyawan merasa puas karena pelatihan kerja yang diberikan sudah sesuai dengan kebutuhan karyawan sehingga karyawan bisa memanfaatkan ilmu yang diterima pada saat pelatihan kerja untuk menyelesaikan pekerjaan.

Hipotesis pertama $(\mathrm{H} 2)$ yang menyatakan bahwa Pelatihan Kerja berpengaruh signifikan terhadap Komitmen Organisasional dapat diterima. Hal ini dibuktikan melalui uji regresi dimana nilai probabilitas ( $p$-value) sebesar 0,009 lebih kecil dari nilai signifikan 0,05 yang menunjukkan hasil yang signifikan. Artinya Pelatihan Kerja, mempunyai pengaruh yang signifikan terhadap Komitmen Organisasional. Data pada statistic deskriptif juga menunjukkan bahwa skor mean variabel Pelatihan Kerja sebesar 4,27 yang termasuk kategori sangat tinggi dan variabel Komitmen Organisasional sebesar 4,30 yang termasuk kategori tinggi. Sebaliknya, penerapan Pelatihan Kerja yang buruk juga akan berpengaruh terhadap Komitmen Organisasional karyawan menjadi rendah.

Koefisien jalur sebesar 0,014 mengindikasikan bahwa pengaruh Pelatihan Kerja terhadap Komitmen Organisasional adalah positif. Artinya, semakin baik persepsi karyawan terhadap Pelatihan Kerja yang diterapkan oleh pemimpin maka akan semakin tinggi persepsi karyawan terhadap Komitmen Organisasional. Demikian pula sebaliknya ketika persepsi karyawan terhadap Pelatihan Kerja buruk, maka persepsi terhadap Komitmen Organisasional juga akan rendah. Berdasarkan jawaban responden dari angket yang terkumpul maka skor mean tertinggi pada indicator isi/ materi pelatihan $(\mathrm{X} 1,1)$ dengan skor mean sebesar 4,67 yang termasuk dalam kategori sangat tinggi dengan item tertingginya adalah tipe ateri pelatihan kerja mampu mengembangkan seluruh kemampuan (Business Skill, Personal Development, dan Technical Skill) (X1,1,2). Hal ini menunjukkan isi materi pelatihan dengan item yang mampu mengembangkan seluruh kemampuan karyawan akan mempengaruhi Komitmen Organisasional.

Hipotesis kedua (H3) yang menyatakan bahwa Insentif berpengaruh signifikan terhadap Kepuasan Kerja dapat diterima. Hal ini dibuktikan melalui uji regresi dimana nilai probabilitas ( $p$ value) sebesar 0,000 lebih kecil dari nilai signifikan
0,05 yang menunjukkan hasil yang signifikan. Artinya Insentif, mempunyai pengaruh yang signifikan terhadap Kepuasan Kerja. Data pada statistic deskriptif juga menunjukkan bahwa skor mean variabel Insentif sebesar 4,34 yang termasuk kategori sangat tinggi dan variabel Kepuasan Kerja sebesar 4,40 yang termasuk kategori tinggi. Sebaliknya, penerapan Insentif yang buruk juga akan berpengaruh terhadap kepuasan kerja karyawan menjadi rendah.

Koefisien jalur sebesar 0,836 mengindikasikan bahwa pengaruh insentif terhadap kepuasan kerja adalah positif. Artinya, semakin baik persepsi karyawan terhadap insentif yang diberikan oleh pemimpin maka akan semakin tinggi persepsi karyawan terhadap kepuasan kerja. Demikian pula sebaliknya ketika persepsi karyawan terhadap insentif buruk, maka persepsi terhadap kepuasan kerja juga akan rendah. Berdasarkan jawaban responden dari angket yang terkumpul maka skor mean tertinggi pada indikator besarnya komisi (insentif) karyawan (X2,2) dengan skor mean sebesar 4,44 yang termasuk dalam kategori sangat tinggi dengan item tertingginya adalah Komisi yang saya terima cukup untuk memenuhi kebutuhan hidup tambahan saya $(X 2,2,3)$. Hal ini menunjukkan bahwa komisi yang diterima karyawan mampu memberikan kepuasan bagi seluruh kemampuan karyawan.

Hipotesis keempat ( $(\mathrm{H} 4)$ yang menyatakan bahwainsentif berpengaruh signifikan terhadap komitmen organisasional terbukti. Hal ini ditunjukkan melalui uji regresi dimana nilai probabilitas ( $p$-value) 0,000 lebih kecil dari nilai signifikan 0,05 yang menunjukkan hasil yang signifikan. artinya karakteristik Insentif mempunyai pengaruh yang signifikan terhadap Komitmen Organisasional. Data pada statistic deskriptif juga menunjukkan bahwa skor mean indikator Bonus (X2.1) sebesar 4,42 sedangankan pada indikator kedua komisi (X2.2) nilai mean sebesar 4,52 pada item peningkatan pemberian komisi dimana dari hasil yang didaptkan pengaruh signifikan.

Hasil penelitian ini didukung penelitian oleh [21]. Hasil uji serempak (uji F) menunjukkan bahwa pemberian insentif dan kepuasan kerja secara serempak berpengaruh signifikan terhadap prestasi kerja karyawan Bali Yasa (PT. Kereta Api Medan. Hasil uji parsial (Uji t) menunjukkan bahwa variabel pemberian insentif dan kepuasan kerja masing-masing berpengaruh signifikan terhadap prestasi kerja karyawan Balai Yasa PT. Kerata Api Medan.

Hasil Penelitian dari [22] berjudul Pengaruh Pemberian Insentif Terhadap Komitmen Kerja KAryawan PT. Bank Rakyat Indonesia Cabang Lubuk Pakam.Hasil penelitian ini menunjukkan 
bahwa pemeberian insentif berpengaruh positif dan signifikan terhadap komitmen kerja karyawan hasil regresi secara keseluruhan menunjukan insentif.

Hipotesis kelima (H5) yang menyatakan bahwa kepuasan kerja berpengaruh signifikan terhadap komitmen organisasional dapat diterima. Hal ini dibuktikan melalui hasil uji regresi diman nilai probabilitas ( $p$-value) sebesar 0,000 lebih kecil dari nilai signifikansi 0,488 yang menunjukkan hasil yang signifikan, Artinya kepuasan kerja mempunyai pengaruh yang signifikan terhadap komitmen organisasional. Data pada statistik deskriptif juga menunjukkan bahwa skor mean pada variabel kepuasan kerja sebesar 4,635 yang termasuk kategori sangat tinggi dan variabel komitmen organisasional sebesar 4,558. Hal tersebut mengindikasikan pengaruh kepusan kerja terhadap komitmen organisasional adalah positif. Artinya semakin baik persepsi karyawan terhadap kepuasan kerja akan menghasilkan persepsi yang tinggi pula komitmen karyawan terhadap organisasinya. Demikian pula sebaliknya ketika persepsinya karyawan terhadap kepuasan kerja rendah, maka persepsi terhadap komitmen organisasional juga akan rendah.

Berdasarkan jawaban responden dari angket yang terkumpul maka skor mean tertinggi indikator kemajuan (Y1.1) dengan skor mean sebesar 4,427 yang termasuk kategori sangat tinggi dengan item memiliki motivasi untuk berprestasi (Y1.1.3) sebesar 4,462yang termasuk kategori sanagt tinggi.

Berdasarkan hasil perhitungan statistic menunjukkan bahwa pelatihan kerja berpengaruh signifikan terhadap komitmen organisasional dengan koefisien jalur sebesar 0,014 dan nilai signifikan 0,009 (sig probabilitas $<0,05$ ). Selanjutnya dilakukan pengujian pengaruh tidak langsung antara pelatihan kerja terhadap komitmen organisasional melalui kepuasan kerja, dan hasil perhitungan menunjukkan koefisien jalur sebesar 0,488 sehingga pengaruh tidak langsung adalah signifikan. Dengan demikian dapat disimpulkan bahwa penerapan pelatihan kerjajuga akan meningkatkan komitmen organisasional.

Berdasarkan hasil perhitungan statistik menunjukkan bahwa insentif signifikan terhadap komitmen organisasional dengan koefisien jalur sebesar 0,511 dan nilai sig sebesar 0,000 (sig probabilitas $<0,05)$. Selanjutnya dilakukan pengujian pengaruh tidak langsung anatara Insentif terhadap komitmen organisasional melalui kepuasan kerja, dari hasil perhitungan menunjukkan koefisien jalur koefisien sebear 0,488 sehingga pengaruh tidak langsung adalah signifikan, karena mempunyai nilai positif dengan demikian dapat disimpulkan bahwa penerapan insentif akan meningkatkan komitmen organisasional, apabila dengan penerapan insentif yang sama mampu meningkatkan kepuasan kerja karyawan.

\section{Kesimpulan}

Berdasarkan hasil analisa data serta pembahasan yang telah dilakukan, maka hasil penelitian ini dapat disimpulkan sebagai berikut:

1. Berdasarkan analisis deskriptif dapat diketahui bahwa keempat variabel penelitian (pelatihan kerja, insentif, kepuasan kerja, serta komitmen organisasional) berada pada skor 4 dan masuk dalam kategori baik atau tinggi.

2. Pelatihan kerja berpengaruh positif dan signifikan terhadap kepuasan kerja. Artinya, pelatihan kerja yang diterapkan oleh pimpinan kepada bawahan akan meningkatkan kepuasan kerja karyawan. Hal ini dibuktikan melalui uji regresi dimana nilai probabilitas ( $p$-value) sebesar 0,000 lebih kecil dari nilai signifikan 0,05 yang menunjukkan hasil yang signifikan.

3. Pelatihan kerja berpengaruh positif dan signifikan terhadap komitmen organisasional, artinya pelatihan kerja yang diberikan oleh PT BRI Cabang Malang Martadinata kepada karyawan mampu meningkatkan komitmen organisasional. Hal ini dibuktikan melalui uji regresi dimana nilai probabilitas ( $p$-value) sebesar 0,000 lebih kecil dari nilai signifikan 0,05 yang menunjukkan hasil yang signifikan.

4. Insentif berpengaruh positif dan signifikan pada kepuasan kerja, arrtinya semakin tinggi persepsi karyawan tentang insentif maka akan semakin tinggi pula tingkat kepuasan kerja karyawan. Hal ini dibuktikan melalui uji regresi dimana nilai probabilitas ( $p$-value) sebesar 0,000 lebih kecil dari nilai signifikan 0,05 yang menunjukkan hasil yang signifikan.

5. Insentif berpengaruh positif dan signifikan terhadap komitmen organisasional pada tingkat signifikasi 0,05 atau pada derajat kepercayaan 95\%, artinya penerapan insentif mempengaruhi persepsi karyawan terhadap komitmen organisasional.Hal ini dibuktikan melalui uji regresi dimana nilai probabilitas ( $p$-value) sebesar 0,000 lebih kecil dari nilai signifikan 0,05 yang menunjukkan hasil yang signifikan.

6. Kepuasan kerja berpengaruh positif terhadap komitmen organisasional, artinya karyawan yang merasa terpenuhinya kepuasan kerja, akan mampu meningkatkan komitmen organisasional. Hal ini dibuktikan melalui uji regresi dimana nilai probabilitas ( $p$-value) sebesar 0,000 lebih kecil dari nilai signifikan 0,05 yang menunjukkan hasil yang signifikan. 


\section{UCAPAN TERIMA KASIH}

Dalam pengerjaan jurnal penelitian ini, peneliti ingin menyampaikan ucapan terimakasih kepada pihak-pihak yang membantu menyelesaikan jurnal ini sampai akhir khususnya kepada dosen pembimbing yaitu Prof. Dr. Endang Siti Astuti, M.Si Dr. Mochammad Al Musadieq, MBA dan Ketua Program Dr. Kertahadi, M. Com

\section{DAFTAR PUSTAKA}

[1]. Hasibuan, Malayu SP. 2000. Manajemen Sumber Daya Manusia. Jakarta: Bumi Aksara

[2]. Handoko, T. Hani. 2008. Manajemen Personalia dan Sumber Daya Manusia (edisi 2).Yogyakarta: BPFE.

[3]. Mangkuprawira,. 2002. Manajemen Sumber Daya Manusia Strategik. Jakarta: Ghalia Indonesia

[4]. Kadarisman, M. 2012. Manajemen Pengembangan Sumber Daya Manusia.Jakarta: Rajagrafindo Persada.

[5]. Luthans, F. 2005. Organizational Behavior (10th ed). New York: McGraw-Hill.

[6]. Spector, P. E., 2001. Industrial and Organizational Psychology Research and Practice (second edition). New York: Jhon Wily \& Sons, Inc.

[7]. Robbins, Stephen. P. 2006. Perilaku Organisasi (alih bahasa Drs. Benjamin Molan), Edisi Bahasa Indonesia, Klaten: PT INT AN SEJATI.

[8]. Choo, Stephen. 2007. Using training and development to affect job satisfaction within franchising" Journal Emerald Group Publishing Limited. Vol. 14 Iss: 2, pp.339 352

[9]. Simamora, Bilson, 2008. Memenangkan Pasar dengan Pemasaran Efektif dan Profitabel. Jakarta: PT. Gramedia Pustaka Utama

[10]. Sutono. 2000. Analisis Pengaruh Pelatihan dan Kepuasan Kerja terhadap Produktivitas Karyawan PT. Sepatu Bata Tbk. Jurnal USU

[11]. Wexley, Kenneth N., dan Gary A. Yuki. 2003. Psikologi Organisasi dan Psikologi Personalia.Jakarta: Rhineka Cipta.

[12]. Hariandja, Marihot. 2007. Manajemen Sumber Daya Manusia. Jakarta: Grasindo.

[13]. Davis, Keith dan Newstrom.1997.Perilaku Dalam Organisasi, Edisi ketujuh, Jakarta: Penerbit Erlangga
[14]. Wesley S. Roehl (2013) "Training and its Impact on Organizational Commitment among Lodging Employees"

[15]. Luthans, Fred. 2006. Perilaku Organisasi, (Alih Bahasa V. A Yuwono, dkk), Edisi Bahasa Indonesia, Yogyakarta: ANDI.

[16]. Sembiring, Samuel Abel Tanta, (2008) Analisis Pengaruh Kepuasan Kerja dan Komitmen organisasional Terhadap Kinerja Karyawan Dengan Motivasi Sebagai Variabel Intervening di Kantor Pusat Operasional (KPO) PT. Bank Aceh

[17]. Saragih, Syaiful Amri. 2010. Analisis Pengaruh Pemberian Insentif Serta Pendidikan Dan Pelatihan Terhadap Peningkatan Kinerja di Guru Dinaspendidikan Di Tebing Tinggi. Jurnal USU

[18]. Notoatmojo, Soekidjo. 2005. Metodologi Penelitian Kesehatan, Jakarta: Rineka Cipta

[19]. Unarjan. 2003. Manajemen Sumber Daya Manusia. Jakarta: Kencana Prenada Media Group.

[20]. Singarimbun, Masri. 2006. Metode Penelititan Survei. LP3S, Jakarta

[21]. Loebis (2008) Pengaruh Pemberian Insentif dan Kepuasan Kerja Terhadap Prestasi Kerja Karyawan Balai Yasa Pulo Brayan PT. Kereta Api Medan

[22]. Nasution, Chairunddin (2010) Pengaruh Pemberian Insentif Terhadap Komitmen Kerja KAryawan PT. Bank Rakyat Indonesia Cabang Lubuk Pakam 